\title{
ANALISA KAPASITAS SALURAN PRIMER TERHADAP PENGENDALIAN BANJIR (Studi Kasus Sistem Drainase Kota Langsa)
}

\author{
Fachrizal $^{1)}$, Wesli ${ }^{2)}$ \\ ${ }^{1)}$ Alumni Teknik Sipil, ${ }^{2)}$ Dosen Jurusan Teknik Sipil, Universitas Malikussaleh \\ email: ${ }^{1)}$ fachrizal65@yahoo.co.id, ${ }^{2)}$ ir_wesli@yahoo.co.id
}

\begin{abstract}
Abstrak
Banjir dan genangan air seringkali terjadi di beberapa wilayah di Kota Langsa, hal ini sering menimbulkan kerugian berupa terganggunya aktivitas masyarakat, terganggunya arus lalu lintas (kemacetan) dan kerugian material. Kawasan permukiman Sungai Paoh Kecamatan Langsa Barat dengan luas area $19.532 \mathrm{Ha}$, sering terjadi banjir genangan khususnya pada musim penghujan. Hal ini disebabkan oleh kondisi saluran drainase eksisting yang ada saat ini tidak dapat menampung atau mengalirkan debit limpasan air hujan. Penelitian dilakukan dengan cara menganalisis kapasitas saluran eksisting sehingga nantinya diperoleh kesesuaian kapasitas saluran drainase dengan debit banjir rencana. Metode perhitungan analisis curah hujan rencana menggunakan metode Gumbel, Log Person Type III, dan Log Normal dimana curah hujan tahunan maksimum rata-rata menggunakan data dari Dinas Kelautan, Perikanan dan Pertanian Kota Langsa. Intensitas curah hujan dihitung menggunakan metode Mononobe, sedangkan debit banjir rencana dihitung menggunakan metode Rasional, dari hasil perhitungan debit banjir rencana dapat ditentukan kemampuan saluran drainase eksisting dalam mengalirkan debit banjir. Berdasarkan hasil analisis, diperoleh kapasitas saluran drainase eksisting sudah tidak mampu menampung atau mangalirkan debit banjir rencana, oleh karena itu perlu dilakukan pembesaran dimensi saluran sesuai dengan debit banjir rencana periode ulang sepuluh tahunan. Berdasarkan debit banjir rencana saluran drainase pias-I sebesar $\left(\mathrm{Q}_{\mathrm{T}}\right) 4.314$ $\mathrm{m}^{3} /$ detik, dan saluran drainase pias-II sebesar $\left(\mathrm{Q}_{\mathrm{T}}\right) 5.318 \mathrm{~m}^{3} /$ detik, maka diperoleh dimensi saluran drainase pias-I dengan lebar saluran $3.50 \mathrm{~m}$, kedalaman air $1.48 \mathrm{~m}$, dengan kemiringan saluran 0.000347 , sedangkan dimensi saluran drainase pias-II dengan lebar saluran $3.50 \mathrm{~m}$, kedalaman air $1.73 \mathrm{~m}$, dengan kemiringan saluran 0.000347 .
\end{abstract}

Kata Kunci : Banjir, Kapasitas Saluran, Dimensi Saluran

\section{Pendahuluan}

Kawasan permukiman Sungai Paoh Kecamatan Langsa Barat, sering terjadi banjir genangan khususnya pada musim penghujan. Hal ini disebabkan oleh kondisi saluran drainase yang ada saat ini tidak dapat menampung limpasan air hujan, ditambah lagi dengan kondisi saluran drainase yang melayani kawasan permukiman Sungai Paoh Kecamatan Langsa Barat masih berupa saluran alami yang dibangun oleh masyarakat sekitar. Namun pada pertegahan tahun 2010 konsultan perencana, sudah melakukan perencaan teknis, khususnya perencanaan saluran drainase untuk menangani masalah banjir yang kerap terjadi pada kawasan permukiman Sungai Paoh Kecamatan Langsa Barat. Setelah pembangunan saluran drainase seselai dilaksanakan, kawasan permukiman Sungai Paoh Kecamatan Langsa Barat masih saja mengalami banjir genangan namun dengan frekuensi, luasan, dan durasi banjirnya yang cenderung menurun. 
Secara umum penelitian ini memiliki manfaat bagi instansi terkait dalam mengambil tindakan untuk menanggulangi permasalahan banjir akibat periode hujan tertentu. Sedangkan manfaat berdasarkan tujuan penelitian diantaranya, dapat mengetahui berapa besar debit banjir rencana yang terjadi pada kawasan permukiman Sungai Paoh Kecamatan Langsa Barat, dapat mengetahui kemampuan saluran drainase eksisting dalam mengalirkan debit banjir rencana, dan dapat menentukan dimensi saluran drainase yang mampu mengalirkan debit banjir rencana.

\section{Tinjauan Kepustakaan}

\subsection{Analisa Hidrologi}

Memurut Wesli (2008), untuk menyelesaikan persoalan drainase sangat berhubungan dengan aspek hidrologi khususnya masalah hujan sebagai sumber air yang akan dialirkan pada sistem drainase dan limpasan sebagai akibat tidak mampunya sistem drainase mengalirkan ke tempat pembuangan akhir.

\subsubsection{Frekuensi dan probabilitas}

Menurut Suripin (2004), analisis frekuensi, didasarkan pada sifat statistik data kejadian yang telah lalu untuk memperoleh probabilitas besaran hujan di masa yang akan datang, dengan anggapan bahwa sifat statistik kejadian hujan yang akan datang masih sama dengan sifat kejadian hujan pada masa lalu. Parameter yang berkaitan dengan analisis data yang meliputi rata-rata, simpangan baku, koefisien variasi, koefisien Skewnees, dan koefisien Curtosis. Parameter statistik adalah sebagai berikut:

Nilai rata-rata

$$
\bar{X} r t=\frac{1}{n} \sum_{i=1}^{n} X_{i}
$$

Standar deviasi

$$
S_{D}=\left\{\frac{1}{n-1} \sum_{i-1}^{n}\left(X_{i}-\bar{X}_{i}\right)^{2}\right\}^{1 / 2}
$$

Koefisien variasi

$$
C_{V}=\frac{S_{D}}{\bar{X}_{i}}
$$

Koefisien kemencengan (Skewness)

$$
C s=\frac{n \sum_{i=1}^{n}\left(X_{i}-\bar{X}_{i}\right)^{3}}{(n-1)(n-2) S_{D}{ }^{3}}
$$

Koefisien kemencengan (Curtosis)

$$
C k=\frac{n^{2} \cdot \sum(X-\bar{X})^{4}}{(n-1)(n-2)(n-3) \cdot S^{4}}
$$

di mana:

$$
\begin{array}{ll}
n \quad=\text { Jumlah data } & S_{D}=\text { Simpangan baku (deviasi standar) } \\
X r t=\text { Nilai rata-rata },(\mathrm{mm}) & C s=\text { Koefisien kemencengan (Sewness) } \\
C_{v}=\text { Koefisien variasi } & C k=\text { Koefisien puncak/Cortosis }
\end{array}
$$




\subsubsection{Analisis curah hujan rencana}

Menurut Suripin (2004), analisis curah hujan rencana didasarkan pada sifat statistik data kejadian yang telah lalu untuk memperoleh probabilitas besaran hujan di masa yang akan datang, dengan anggapan bahwa sifat statistik kejadian hujan yang akan datang masih sama dengan sifat kejadian hujan pada masa lalu. Tiap tahun diambil hanya satu besaran maksimum yang dianggap berpengaruh pada analisis selanjutnya. Apabila jumlah populasi yang terbatas (sampel), maka persamaan dapat didekati dengan persamaan berikut:

$$
X=\bar{X}+s . K
$$

Persamaan untuk distribusi Log Pearson III dan Log Normal

$$
\log X_{t}=\log \bar{X}+s . K
$$

dimana:

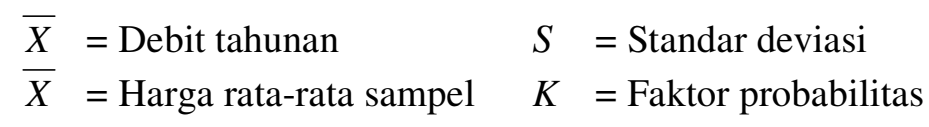

\subsubsection{Uji kecocokan distribusi}

Menurut Wesli (2008), menentukan kecocokan distribusi frekwensi dari sampel data terhadap fungsi distribusi peluang yang diperkirakan dapat menggambarkan atau mewakili distribusi frekwensi tersebut diperlukan pengujian parameter. Prosudur untuk uji Smirnov-Kolmogorov ini dilakukan dengan cara sebagai berikut:

a. Urutkan data dari besar ke kecil dan tentukan peluang dan masing-masing data tersebut dengan rumus:

$$
P=\frac{m}{n+1} x 100 \%
$$

dimana:

$$
\begin{aligned}
& P=\text { Peluang (\%) } \quad n=\text { Jumlah data } \\
& m=\text { Nomor urut data }
\end{aligned}
$$

b. Tentukan peluang teoritis untuk masing-masing data tersebut berdasarkan persamaan distribusinya.

$$
P^{\prime}=\frac{1}{T}
$$

c. Dari kedua nilai peluang tersebut, tentukan nilai selisih terbesar antara peluang pengamatan dengan peluang teoritis :

$$
D=\text { maksimum }\left[P\left(Q_{\text {maks }}\right)-P^{\prime}\left(Q_{\text {maks }}\right)\right]
$$

d. Berdasarkan tabel nilai kritis uji Smirnov-Kolmogorov ditentukan harga Do.

e. Apabila D lebih kecil dari Do maka distribusi yang digunakan untuk menentukan debit rencana dapat diterima, sebaliknya jika harga D lebih besar dari Do, maka distribusi yang digunakan untuk menentukan debit rencana tidak diterima.

\subsubsection{Koefisien aliran permukaan}

Menurut Suripin (2004), koefisien aliran permukaan (C) didefinisikan sebagai nisbah antara puncak aliran permukaan terhadap intensitas hujan. Faktor 
ini merupakan variabel yang menentukan hasil perhitungan debit banjir. Koefesien limpasan juga tergantung pada sifat dan kondisi tanah. Nilai koefisien aliran permukaan $(\mathrm{C})$ dihitung dengan persamaan berikut:

$$
C_{D A S}=\frac{\sum_{i=1}^{n} C_{i} A_{i}}{\sum_{i=1}^{n} A_{i}}
$$

dimana:

$$
\begin{aligned}
& A_{i}=\text { Luas lahan penutup tanah }(i) \\
& C_{i}=\text { Koefisien aliran permukaan } \\
& n=\text { Jumlah jenis penutup lahan }
\end{aligned}
$$

\subsubsection{Waktu konsentrasi, (Tc)}

Menurut Wesli (2008), waktu konsentrasi adalah waktu yang diperlukan untuk mengalirkan air dari titik paling jauh pada daerah aliran ke titik kontrol yang ditentukan di bagian hilir suatu saluran. Waktu konsentrasi drainase perkotaan terdiri dari waktu yang diperlukan air untuk mengalir melalui permukaan tanah dari tempat terjauh ke saluran terdekat ditambah waktu untuk mengalir didalam saluran ke tempat pengukuran. Waktu konsentrasi dihitung dengan rumus berikut:

$$
t_{c}=t_{o}+t_{d}
$$

di mana:

$$
\begin{aligned}
t c= & \text { Waktu konsentrasi (menit) } \\
t o= & \text { Inlet Time, waktu yang diperlukan air hujan mengalir dipermukaan } \\
& \text { tanah dari titik terjauh ke saluran terdekat (menit) } \\
t d= & \text { Conduit Time, waktu yang diperlukan air hujan untuk mengalir di } \\
& \text { dalam saluran sampai ke tempat pengukuran (menit) }
\end{aligned}
$$

\subsubsection{Intensitas hujan, (I)}

Menurut Suripin (2004), intensitas hujan adalah tinggi atau kedalaman air hujan per satuan waktu. Sifat umum hujan adalah makin singkat hujan berlangsung intensitasnya cenderung makin tinggi dan makin besar periode ulangnya makin tinggi pula intensitasnya. Apabila data hujan jangka pendek tidak tersedia, yang ada hanya data hujan harian, maka intensitas hujan dapat dihitung dengan rumus Mononobe sebagai berikut:

$$
I=\frac{R_{24}}{24}\left(\frac{24}{t}\right)^{\frac{2}{3}}
$$

di mana:

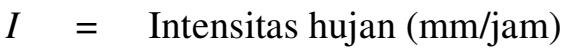

$t=$ Lamanya hujan (jam)

$R_{24}=$ Curah hujan maksimum harian (mm)

\subsubsection{Debit banjir rencana}

Menurut Suripin (2004), metode perhitungan debit banjir yang dipakai pada suatu lokasi lebih banyak ditentukan oleh ketersediaan data. Metode rasional 
dikembangkan berdasarkan asumsi bahwa hujan yang terjadi mempunyai intensitas seragam dan merata di seluruh daerah pengaliran selama paling sedikit sama dengan waktu konsentrasi, tc daerah pengalirannya. Persamaan matematis metode rasional dinyatakan dalam bentuk berikut:

$$
Q=0.00278 \text { C.I.A }
$$

di mana:

$Q=$ Debit rencana $\left(\mathrm{m}^{3} / \mathrm{det}\right)$

$C=$ Koefisien aliran permukaan $(0 \leq C \leq 1)$

$I=$ Intensitas hujan selama waktu konsentrasi, $(\mathrm{mm} / \mathrm{jam})$

$A=$ Luas daerah aliran (Ha)

\subsection{Desain Hidrolika}

\subsubsection{Geoeometrik penampang saluran}

Menurut Chow (1997), unsur-unsur geometrik adalah sifat-sifat suatu penampang saluran yang dapat diuraikan seluruhnya berdasarkan geometrik penampang dan kedalaman aliran. Unsur ini sangat penting dan banyak sekali dipakai dalam perhitungan aliran.

Tabel 1. Unsur Geometris Penampang Saluran

\begin{tabular}{|c|l|l|}
\hline No. & \multicolumn{1}{|c|}{ Penampang } & Persegi Panjang \\
\hline 1 & Luas (A) & $A=b \cdot y$ \\
\hline 2 & Keliling basah (P) & $P=b+2 y$ \\
\hline 3 & Jari-jari hidrolik (R) & $R=\frac{b y}{b+2 y}$ \\
\hline
\end{tabular}

Sumber: Chow, 1997

\subsubsection{Dimensi saluran}

Menurut Wesli (2008), dimensi saluran harus mampu mengalirkan debit banjir rencana atau dengan kata lain debit yang dialirkan oleh saluran $\left(\mathrm{Q}_{\mathrm{S}}\right)$ sama atau lebih besar dari debit rencana $\left(\mathrm{Q}_{\mathrm{T}}\right)$.

$$
Q_{S} \geq Q_{T}
$$

Debit suatu penampang saluran (Qs) dapat diperoleh dengan menggunakan rumus seperti di bawah ini.

$$
Q_{S}=A_{S} \cdot V
$$

Kecepatan rata-rata aliran di dalam saluran dapat dihitung dengan menggunakan rumus Manning sebagai berikut:

$$
\begin{aligned}
& V=\frac{1}{n} R^{2 / 3} S^{1 / 2} \\
& R=\frac{A s}{P}
\end{aligned}
$$

di mana:

$\mathrm{V}$ = Kecepatan rata-rata aliran di dalam saluran (m/det)

$\mathrm{n} \quad=$ Koefisien kekasaran Manning

$\mathrm{R}=$ Jari-jari hidrolis ( $\mathrm{m}$ )

$\mathrm{S}=$ Kemiringan dasar saluran 
As $=$ Luas penampang saluran tegak lurus arah aliran $\left(\mathrm{m}^{2}\right)$

$\mathrm{P} \quad=$ Keliling basah saluran $(\mathrm{m})$

Tinggi jagaan adalah jarak vertikal antara tinggi saluran dengan muka air pada kondisi rencana. Jarak ini harus cukup untuk mencegah kenaikan muka air yang melimpah. Beasaran tinggi jagaan yang umum dipakai dalam perencanaan saluran drainase berkisaran antara 5\% sampai lebih besar dari $30 \%$ dari kedalaman air. Tinggi jagaan dihitung dengan menggunakan persamaan berikut:

$$
F=\sqrt{C \cdot y}
$$

di mana:

$$
\begin{aligned}
F= & \text { Tinggi jagaan }(\mathrm{ft}) \\
y= & \text { Kedalaman air dalam saluran }(\mathrm{ft}) \\
C= & \text { Keofesien, } 1,5 \text { untuk saluran berkapasitas } 20 \mathrm{ft}^{2} / \mathrm{dt} \text { sampai } 2,5 \text { untuk } \\
& \text { saluran berkaasitas } 3000 \mathrm{ft}^{2} / \mathrm{dt}
\end{aligned}
$$

\section{Metode Penelitian}

Data primer adalah data yang diperoleh dari lokasi rencana pembangunan maupun hasil survey yang dapat langsung dipergunakan sebagai sumber dalam perancangan bangunan. Data primer dalam penelitian ini meliputi peta Provinsi Aceh, peta Kota Langsa, skema jaringan saluran (Layout), dan gambar desain saluran drainase. Data sekunder merupakan data pendukung yang dipakai dalam proses perencanaan sistem drainase di kawasan permukiman Sungai Paoh Kecamatan Langsa Barat. Data sekunder dalam penelitian ini meliputi data curah hujan, peta topografi, dan foto satelit lokasi peninjauan. Tahapan pelaksanaan penelitian ini meliputi studi literatur, pengumpulan data, dan melakukan pengolahan data untuk mendapatkan hasil penelitian. Tahapan pelaksanaan penelitian analisa kemampuan saluran drainase di kawasan permukiman Sungai Paoh Kecamatan Langsa Barat, diantaranya sebagai berikut:

1. Mengumpulkan literatur dari bebrapa buku yang berkenaan dengan sistem drainase perkotaan, hidrologi pengairan, dan hidrolika saluran.

2. Mengumpulkan data-data yang diperlukan yang terdiri dari data primer dan data sekunder.

3. Pengelohan data dilakukan dengan menganalisa data curah hujan dengan menggunakan distribusi Gumbel, Log Pearson, dan Log Normal, menganalisa frekuensi probabilitas dan melakukan uji kecocokan distribusi. Kemudian dilanjutkan dengan menganalisa waktu konsentrasinya dihitung dengan persamaan Kirpich, dan menentukan nilai koefisien aliran permukaan, kemudian menganalisa intensitas hujan, dihitung menggunakan persamaan Mononobe. Setelah itu dapat menentukan debit banjir rencana menggunakan metode Rasional dengan periode ulang 10 tahunan, dilanjutkan dengan menghitung kapasitas saluran drainase yang tersedia apakah cukup menampung debit banjir puncak atau tidak, jika tidak perlu direncanakan dimensi saluran baru sesuai dengan debit banjir rencana.

\section{Hasil dan Pembahasan}

\subsection{Analisis curah hujan rencana}

Hujan rencana merupakan curah hujan terbesar tahunan dengan peluang tertentu. Besar curah hujan rencana dihitung dengan menganalisa probabilitas 
frekuensi curah hujan. Beberapa metoda tersedia akan disesuaikan dengan distribusi datanya, diantaranya metode Gumbel, Log Person III, dan Log Normal. Hasil perhitungan analisa curah hujan rencana berdasarkan masing-masing periode periode ulang seperti diperlihatkan pada Tabel 2.

Tabel 2 Analisa Curah Hujan Rencana Menurut Distribusi Gumbel

\begin{tabular}{|c|c|r|r|r|}
\hline No. & $\begin{array}{c}\text { Periode Ulang } \\
\text { (Tahun) }\end{array}$ & $\begin{array}{c}\text { Reducen Variate } \\
(\mathbf{Y t})\end{array}$ & $\begin{array}{c}\text { Faktor Frekuensi } \\
(\mathbf{k})\end{array}$ & $\begin{array}{c}\text { Ekstrapolasi (Xt) } \\
(\mathbf{m m})\end{array}$ \\
\hline \hline 1. & 2 & 0.3668 & -0.1475 & 385.703 \\
\hline 2. & 5 & 1.5004 & 0.9191 & 469.238 \\
\hline 3. & 10 & 2.2510 & 1.6253 & 524.551 \\
\hline 4. & 20 & 2.9709 & 2.3027 & 577.601 \\
\hline 5. & 25 & 3.1993 & 2.5176 & 594.431 \\
\hline 6. & 50 & 3.9028 & 3.1795 & 646.273 \\
\hline 7. & 100 & 4.6012 & 3.8367 & 697.738 \\
\hline
\end{tabular}

\subsection{Koefisien aliran permukaan}

Koefisien aliran (C) merupakan faktor yang paling menentukan hasil perhitungan debit banjir. Untuk pembagian Chactment Area diperlihatkan pada Gambar1. Sedangkan untuk hasil perhitungan nilai koefisien aliran dan luas Chactment Area 1, luas Chactment Area 2, dan luas Chactment Area 3, seperti diperlihatkan pada Tabel 3.

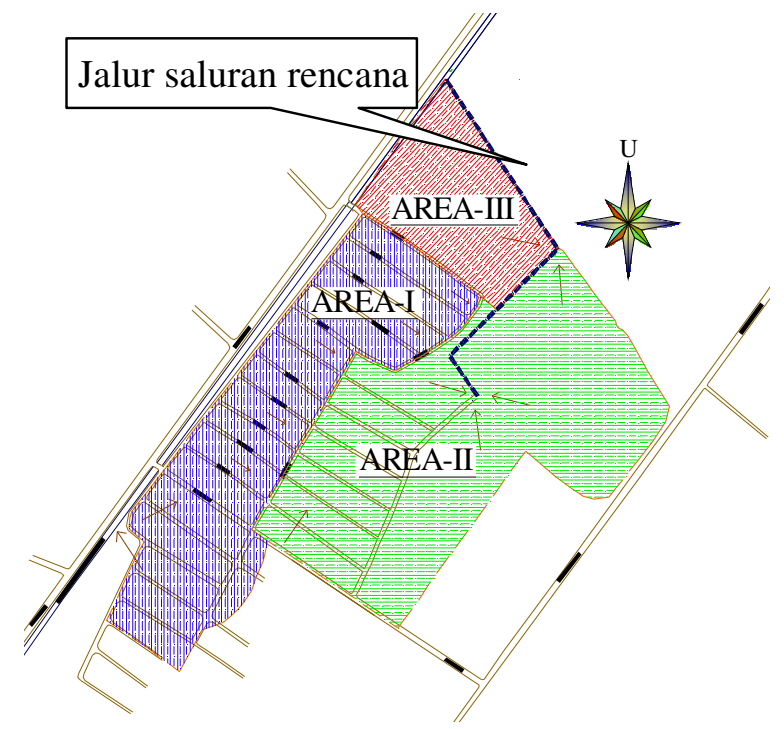

Gambar 1 Peta Pembagian Chactment Area Permukiman Sungai Paoh

Tabel 3. Luas Pemanfaatan Chactment Area

\begin{tabular}{|c|c|c|c|}
\hline No. & Area & Luas Area (Ha) & Nilai Koefisien aliran (C) \\
\hline \hline 1. & Area -1 & 6.944 & 0.91 \\
\hline 2. & Area -2 & 9.663 & 0.78 \\
\hline 3. & Area -3 & 2.925 & 0.76 \\
\hline
\end{tabular}

\subsection{Waktu konsentrasi, (Tc)}

Berdasarkan curah hujan rencana periode ulang 10 tahunan sebesar 524.551 $\mathrm{mm}$, kemiringan permukaan tanah (So) 0.00002, dengan kondisi saluran eksisting 
lebar saluran 3.00 meter, kedalaman saluran 1.00 meter, koefisien Manning 0.020, maka perhitungan waktu konsentrasi (Tc) pada pias-I.a, dengan jarak aliran terjauh (Lo) $500 \mathrm{~m}$, dan panjang saluran (L) $154.90 \mathrm{~m}$, diperoleh waktu konsentrasi (tc) 2.507 jam. Pias-I.b, jarak aliran terjauh (Lo) $300 \mathrm{~m}$, panjang saluran (L) $154.90 \mathrm{~m}$, diperoleh waktu konsentrasi (tc) 1.754 jam. Pias-II, jarak aliran terjauh (Lo) $150 \mathrm{~m}$, panjang saluran (L) $300 \mathrm{~m}$, diperoleh waktu konsentrasi (tc) 1.177 jam. Perhitungan waktu konsentrasi (Tc), diperlihatkan pada Tabel 4.

\subsection{Intensitas hujan (I)}

Berdasarkan curah hujan rencana periode ulang 10 tahunan sebesar 524.551 $\mathrm{mm}$, dengan kondisi saluran eksisting lebar saluran 3.00 meter, kedalaman saluran 1.00 meter, koefisien kekasaran Manning 0.020, maka perhitungan intensitas curah hujan dapat diselesaikan dengan menggunakan rumus Momonobe, dengan waktu konsentrasi tc 2.570 jam, diperoleh nilai intensitas curah hujan (I) 96.929 mm/jam. Hasil perhitungan intensitas curah hujan (I), diperlihatkan pada Tabel 4.

\subsection{Debit banjir rencana}

Metode yang digunakan untuk memperkirakan besarnya debit banjir rencana adalah metode Rasional. Berdasarkan curah hujan maksimum periode ulang 10 tahunan sebesar $524.551 \mathrm{~mm}$, dan kondisi saluran eksisting lebar saluran 3.00 meter, kedalaman saluran 1.00 meter, koefisien Manning 0.020, maka perhitungan debit banjir rencana $\left(\mathrm{Q}_{\mathrm{T}}\right)$ dapat dihitung. Debit banjir rencana, dihitung menggunakan metode Rasional, dengan perolehan nilai debit banjir pada saluran primer pias-I.a yaitu $\left(\mathrm{Q}_{\mathrm{T}}\right) 1.696 \mathrm{~m} 3 /$ detik, pada saluran primer pias-I.b dengan nilai $\left(\mathrm{Q}_{\mathrm{T}}\right) 2.618 \mathrm{~m} 3 /$ detik, dan pada saluran primer pias-II dengan nilai $\left(\mathrm{Q}_{\mathrm{T}}\right) 1.003 \mathrm{~m} 3 /$ detik. Hasil perhitungan debit banjir rencana $\left(\mathrm{Q}_{\mathrm{T}}\right)$, diperlihatkan pada Tabel 4.

Tabel 4 Rekapitulasi Hasil Perhitungan

\begin{tabular}{|c|c|c|c|c|c|c|c|}
\hline No. & $\begin{array}{c}\text { Kode } \\
\text { Saluran }\end{array}$ & $\begin{array}{l}\text { Kode } \\
\text { Area }\end{array}$ & $\begin{array}{c}\text { Waktu Konsentrasi } \\
\text { (Tc) } \\
\text { jam } \\
\end{array}$ & $\begin{array}{c}\text { Koef. } \text { Runoff } \\
\text { (C) } \\
- \\
\end{array}$ & $\begin{array}{c}\text { Intensitas } \\
\quad \text { (I) } \\
\mathrm{mm} / \mathrm{jam} \\
\end{array}$ & $\begin{array}{c}\text { Luas } \\
\text { (A) } \\
\mathrm{Ha} \\
\end{array}$ & $\begin{array}{c}\text { Debit Banjir } \\
\left(\mathbf{Q}_{\mathrm{T}}\right) \\
\mathrm{m}^{3} / \text { detik } \\
\end{array}$ \\
\hline $\mathbf{A}$ & \multicolumn{7}{|c|}{ Saluran Primer (Pias - I.a) } \\
\hline 1 & SP. P-I.a & Area-1 & 2.570 & 0.91 & 96.929 & 6.944 & 1.696 \\
\hline B & \multicolumn{7}{|c|}{ Saluran Primer (Pias - I.b) } \\
\hline 1 & SP. P-I.b & Area-2 & 1.754 & 0.78 & 125.014 & 9.663 & 2.618 \\
\hline $\mathbf{C}$ & \multicolumn{7}{|c|}{ Saluran Primer (Pias - II) } \\
\hline 1 & SP. P-II & Area-3 & 1.177 & 0.76 & 163.095 & 2.925 & 1.003 \\
\hline
\end{tabular}

\subsection{Disain hidrolika}

Berdasarkan curah hujan rencana periode ulang 10 tahunan sebesar 524.551 $\mathrm{mm}$, dan nilai koefisien Manning 0.020, maka debit banjir rencana untuk masingmasing pias saluran dapat ditentukan. Debit banjir rencana saluran primer pias I.a dan pias I.b diperoleh sebesar $\left(\mathrm{Q}_{\mathrm{T}}\right) 4.314 \mathrm{~m}^{3} /$ detik, sedangkan kapasitas saluran primer pias I.a dan pias I.b dalam mengalirkan debit banjir sebesar $\left(\mathrm{Q}_{\mathrm{S}}\right) 4.323$ $\mathrm{m}^{3} /$ detik, jadi saluran primer pias I.a dan pias I.b mampu mengalirkan debit banjir rencana karena debit saluran lebih besar dari pada debit banjir rencana. Sedangkan saluran primer pias II, dengan debit banjir $\left(\mathrm{Q}_{\mathrm{T}}\right) 5.318 \mathrm{~m}^{3} /$ detik dan kemampuan saluran dalam mengalirkan debit banjir sebesar $\left(\mathrm{Q}_{\mathrm{S}}\right) 5.336 \mathrm{~m}^{3} /$ detik, maka saluran 
primer pias II mampu mengalirkan debit banjir rencana karena debit saluran lebih besar dari pada debit banjir rencana. Gambar skema jaringan kapsitas saluran primer permukiman Sungai Paoh Kecamatan Langsa Barat, dengan debit banjir rencana sesuai hasil analisis, seperti diperlihatkan pada Gambar 3.

Tinggi jagaan (Free Board) merupakan jarak vertikal antara tinggi saluran dengan muka air pada kondisi yang direncanakan. Jarak ini harus cukup untuk mencegah kenaikan muka air yang melimpah. Faktor tinggi jagaan (Free Board) merupakan salah satu hal yang sangat penting terutama dalam perencanaan saluran drainase. Besaran tinggi jagaan yang umum dipakai dalam perencanaan saluran drainase berkisaran antara 5\% sampai lebih besar dari $30 \%$ dari kedalaman air, jadi tinggi jagaan saluran drainase pada pias-I dan Pias-II diambil $30 \%$ dari tinggi muka air dalam saluran. Gambar 2, menggambarkan dimensi saluran dan nilai tinggi jagaan sesuai dengan hasil analisis.
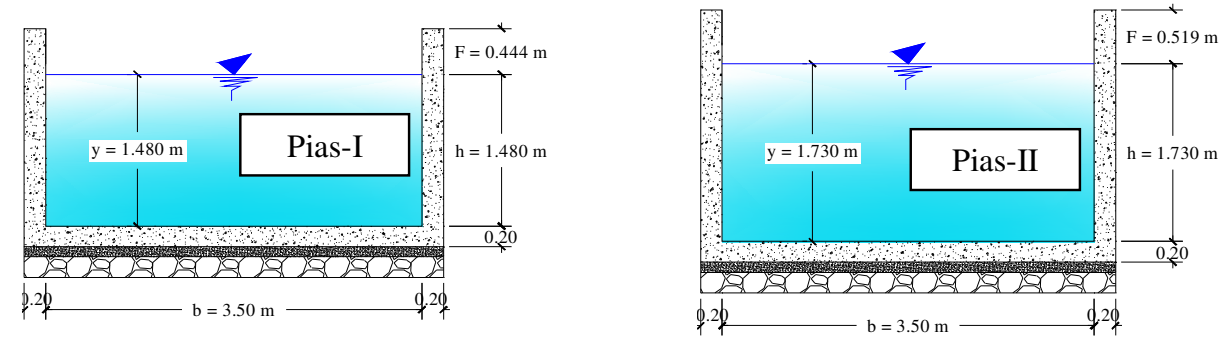

Gambar 2 Penampang Saluran Drainase Pias-I dan Pias-II

\subsection{Pembahasan}

Masalahan banjir genangan yang terjadi di kawasan Permukiman Sungai Paoh, disebabkan oleh tidak mampunya saluran drainase eksisting mengalirkan debit banjir yang dilimpahkan dari masing-masing kawasan tinjauan. Solusi yang dapat diambil dari permasalahan ini yaitu dengan cara malakukan perencanaan jalur saluran baru yang diharapkan dapat mengurangi baban saluran drainase eksisting pada pias-I dan pias-II dalam mengalirkan debit banjir. Sedangkan untuk mengaplikasikan dimensi saluran drainase sesuai dengan hasil perhitungan yang dilakunan penulis dianggap tidak mungkin dilakukan, karena harus melakukan pembongkaran pada saluran drainase eksisting yang sudah ada. Sedangkan saluran pembuang sebagai pengendalian banjir kota Langsa, khususnya pada daerah Permukiman Sungai Paoh Kecamatan Langsa Barat, dengan debit banjir yang diteriama saluran pembuang diasumsikan sama dengan debit banjir yang terjadi pada kawasan tinjauan yaitu sebesar $5.318 \mathrm{~m}^{3} /$ detik, maka diasumsikan yang menjadi beban saluran pembuang dalam mengalirkan debit banjir terdiri dari dua kawasan ditambah dengan satu kawasan tinjauan, jadi total debit banjir yang menjadi beban saluran pembuang sebesar $15.953 \mathrm{~m}^{3} /$ detik, sedangkan debit yang mampu dialirkan saluran pembuang sebesar $16.036 \mathrm{~m}^{3} /$ detik dengan lebar saluran (b) $5.00 \mathrm{~m}$, kedalaman saluran (h) $2.10 \mathrm{~m}$, dan kemiringan saluran (S) 0.000440 . Dengan debit saluran pembuang lebih besar dari pada debit banjir yang dilimpahkan oleh seluruh kawasan sekitar Permukiman Sungai Paoh, maka saluran pembuang sebagai pengendalian banjir kota Langsa mampu mengalirkan debit banjir yang dilimpahkan dari seluruhan kawasan tersebut, jadi dengan demikian tidak ada kemungkinan terjadinya air balik dari saluran pembuang yang 
akan menggenangi sebagian daerah tinjauan khususnya daerah Permukiman Sungai Paoh Kecamatan Langsa Barat. Skema jaringan saluran pembuang sebagai pengendalian banjir kota Langsa, diperlihatkan pada Gambar 3.

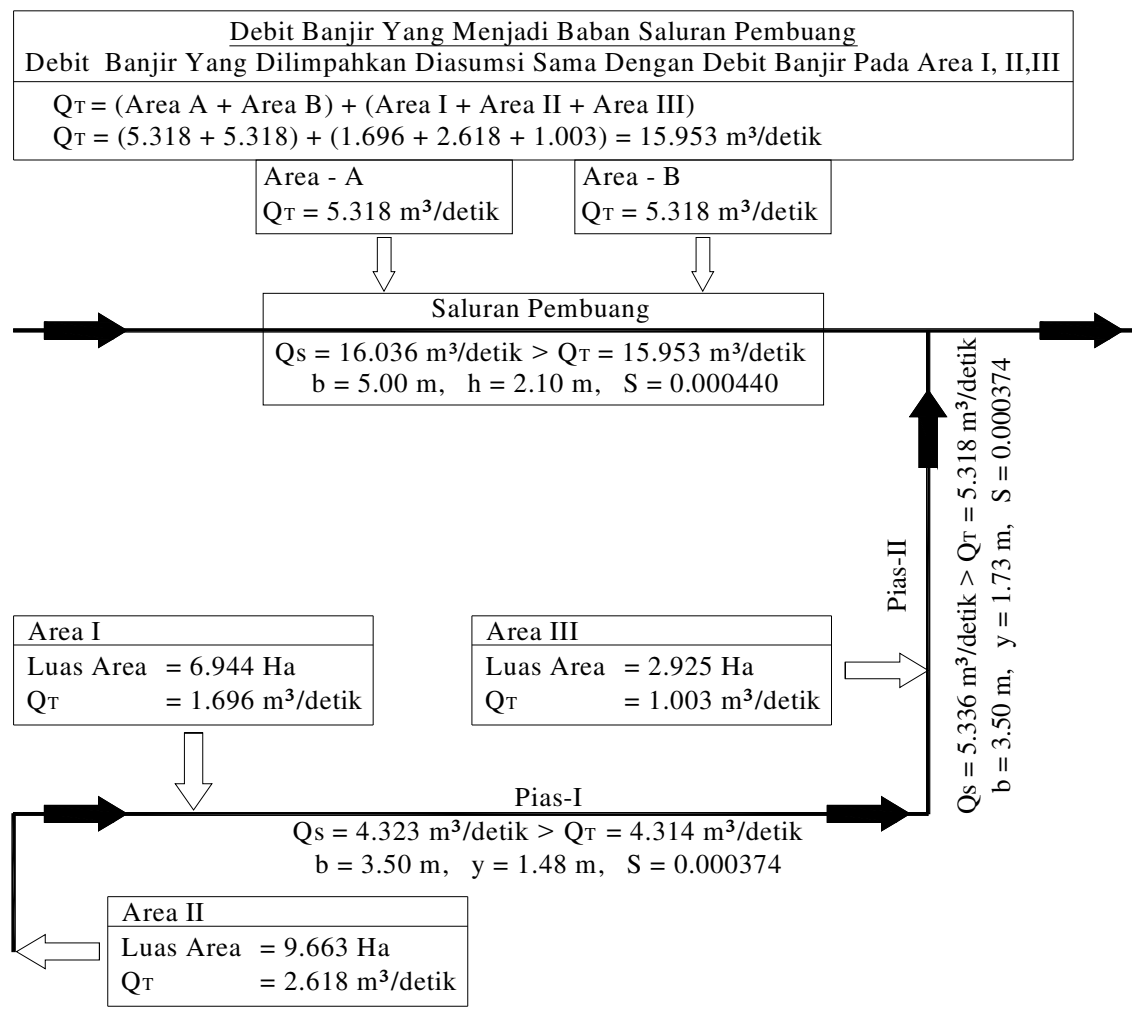

Gambar 3. Skema Jaringan Saluran Drainase Rencana

\section{Kesimpulan dan Saran}

\subsection{Kesimpulan}

Dari uraian yang telah dijelaskan sebelumnya, maka dapat disajikan beberapa kesimpulan diantaranya:

1. Berdasarkan hasil analisis terhadap kapasitas saluran primer eksisting pias-I dan pias-II kawasan permukiman Sungai Paoh Kecamatan Langsa Barat, diketahui bahwa saluran primer eksisting pias-I dan pias-II sudah tidak mampu menampung atau mengalirkan debit banjir rencana yang dilimpahkan oleh masing-masing kawasan tersebut. Dimensi saluran drainase yang mampu mangalirkan debit banjir rencana, pada pias-I yaitu lebar saluran (b) $3.50 \mathrm{~m}$, kedalaman air (y) $1.48 \mathrm{~m}$, dan tinggi jagaan (F) $0.444 \mathrm{~m}$ dengan kemiringan saluran (S) 0.000374. Sedangkan dimensi saluran drainase pias-II, lebar saluran (b) $3.50 \mathrm{~m}$, kedalaman air (y) $1.73 \mathrm{~m}$, dan tinggi jagaan (F) $0.519 \mathrm{~m}$ dengan kemiringan saluran (S) 0.000374.

2. Saluran pembuang sebagai pengendalian banjir kota Langsa, khususnya pada daerah sekitar Sungai Paoh Kecamatan Langsa Barat dengan debit banjir yang diteriama saluran pembuang diasumsikan sama dengan debit banjir pada kawasan tinjauan sebesar $5.318 \mathrm{~m}^{3} /$ detik, dan terdapat dua kawasan disekitar lokasi tinjauan yang melimpahkan debit banjir sebesar $15.953 \mathrm{~m}^{3} /$ detik. 
Sedangkan debit banjir yang mampu dialirkan saluran pembuang sebasar $16.036 \mathrm{~m}^{3} /$ detik. Hal ini menunjukan bahwa kemungkinan terjadinya air balik dari saluran pembuang yang akan menggenangi sebagian daerah tinjauan tidak akan terjadi, karena debit saluran pembuang lebih besar dari pada debit banjir limpasan kawasan sekitar permukiman Sungai Paoh.

\subsection{Saran}

Berdasarkan hasil penelitian dan kesimpulan diatas, dapat diberikan saransaran sebagai rekomendasi sebagai berikut:

1. Hasil penelitian ini, diharapkan menjadi masukan yang berguna dalam proses pengambilan keputusan untuk kepentingan perencanaan sistem saluran drainase yang berkelanjutan khususnya pada daerah permukiman Sungai Paoh Kecamatan Langsa Barat.

2. Penelitian ini dapat dilanjutkan dengan menganalisa luasan bidang wilayah yang harus disediakan untuk resapan air guna kompensasi terhadap penggunaan lahan dan perubahan fungsi tata guan lahan.

\section{Daftar Kepustakaan}

Anonim, 2010, Laporan Akhir Pekerjaan Perencanaan Pengembangan Infrastruktur Kota Langsa (Paket Pr-Infra 13/2010), CV. Ziyad Idola Consultant, Dinas Bina Marga dan Cipta Karya Provinsi, Banda Aceh.

Chow, V, T, 1997, Hidrolika Saluran Terbuka, terjemahan Nensi Rosalina, Erlangga, Jakarta.

Kodoatie R, J, \& Sjarief, R, 2005, Pengelolaan Sumber Daya Air Terpadu, Andi, Yogyakarta.

Soewarno, 1995, Hidrologi Aplikasi Metode Statistik Analisa Data Jilid 2, Nova, Bandung.

Suripin, 2004, Sistem Drainase Perkotaan yang Berkelanjutan, Andi Offset, Yogyakarta.

Wesli, 2008, Drainase Perkotaan, Graha ilmu, Yogyakarta. 


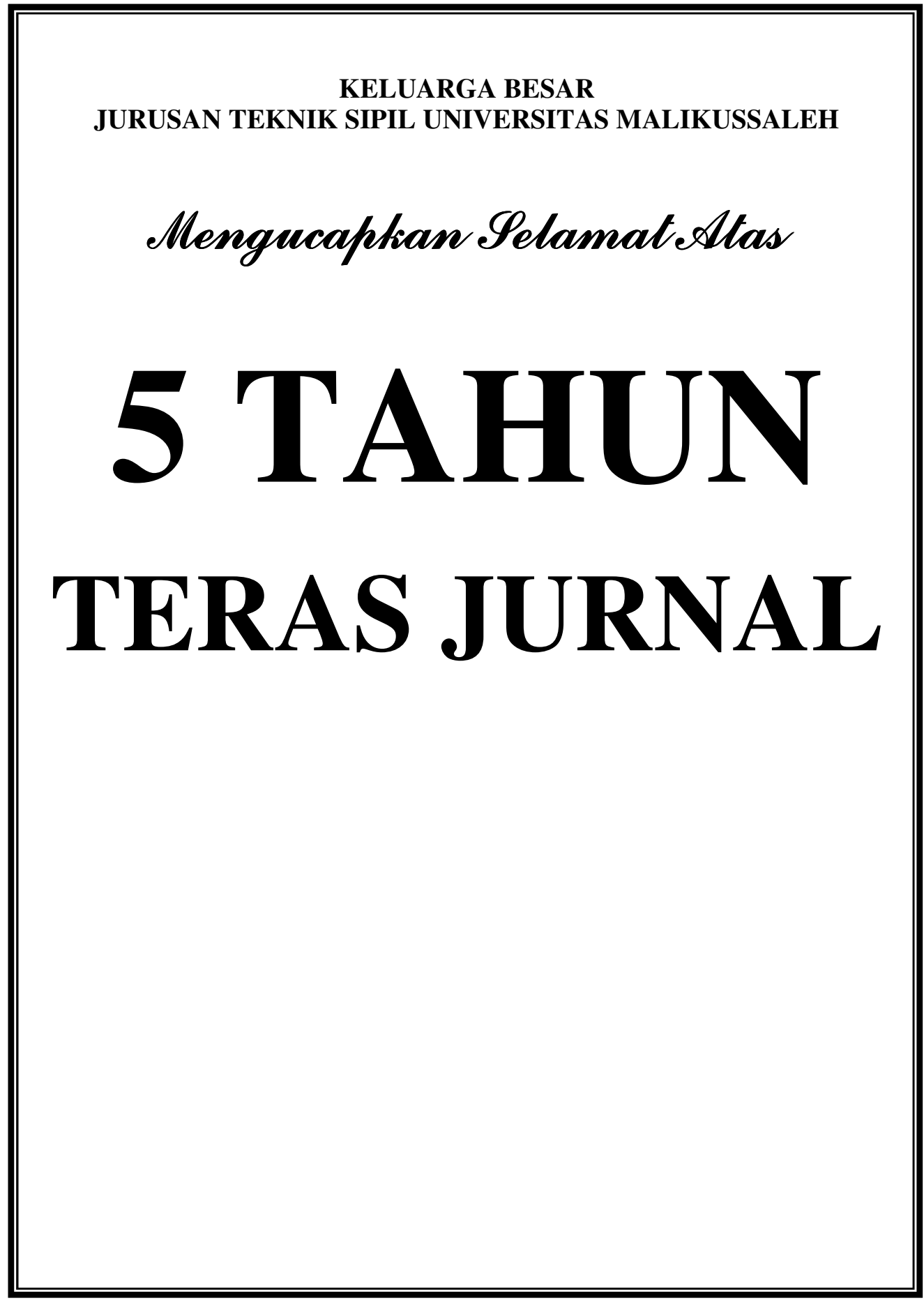

